\title{
What Would the Lab Do In Case of a Complete Test Ban
}

\author{
M. M. May
}

\section{DISCLAIMER}

This report was prepared as an account of work sponsored by an agency of the United States Government. Neither the United States Government nor any agency thereof, nor any of their employees, makes any warranty, express or implied, or assumes any legal liability or responsibility for the accuracy, completeness, or usefulness of any information, apparatus, product, or process disclosed, or represents that its use would not infringe privately owned rights. Reference herein to any specific commercial product, process, or service by trade name, trademark, manufacturer, or otherwise does not necessarily constitute or imply its endorsement, recommendation, or favoring by the United States Government or any agency thereof. The views and opinions of authors expressed herein do not necessarily state or reflect those of the United States Government or any agency thereof.

RECENED

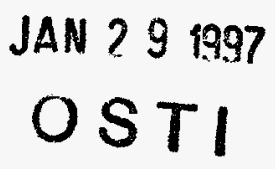

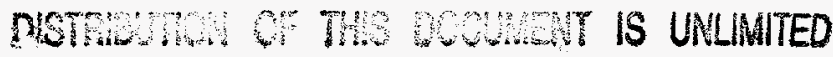

This is an informal report intended primarily for internal or limited external distribution. The opinions and conclusions stated are those of the author and may or may not be those of the Laboratory.

Work performed under the auspices of the U.S. Department of Energy by the Lawrence Livermore National Laboratory under Contract W-7405-ENG-48.

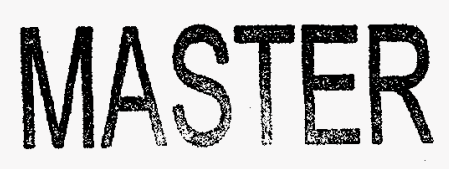




\section{DISCLAIMER}

Portions of this document may be illegible in electronic image products. Images are produced from the best available original document. 
Form AEC-321 (4-64) AECM 0270

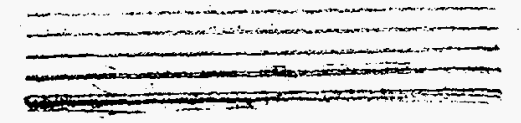

(NSERT CASETFICATION (If classified)

U.S. ATOMIC ENERGY COMMISSION

OUTGOING TELECOMMUNICATION MESSAGE

$$
\text { (See vecerse side for instructions) }
$$

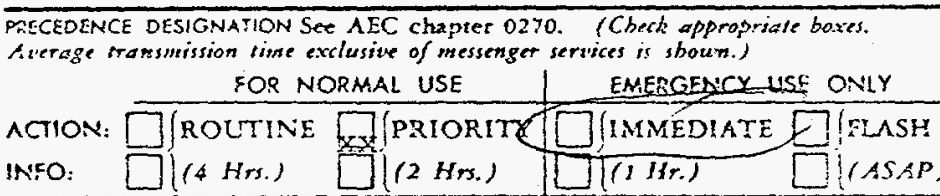

FROA:

MICHAEI M. MAY

IRL, IIVERMORE

\begin{tabular}{|c|c|c|c|}
\hline \multirow{2}{*}{$\begin{array}{l}\text { TYAE OF MESSAGE } \\
\text { (Check one) } \\
\square \text { SINGIE AOORESS } \\
\square \text { MUITIRE ADORESS } \\
\square \text { NOOK MESSAGE }\end{array}$} & \multicolumn{3}{|c|}{ FOR COMMUNICATION CENTER USE } \\
\hline & \multicolumn{2}{|c|}{ MESSAGE IDENTIFICAIION } & $\pi$ \\
\hline $\begin{array}{l}\text { OFFICIAL SUSTNESS } \\
6 / 5\end{array}$ & $R=$ & & $\begin{array}{l}\text { A.M. } \\
P . M\end{array}$ \\
\hline DATE: & $; 1$ & & \\
\hline
\end{tabular}

COMMUNICATION CENTER ROUTING

U. S. ATOMIC ENERGY COMMISSION

DIVISION OF INTERNATIONAL AFFAIRS

ATTN: H. D. BENGEISDORF, ASST. TO THE AGMIA WASHINGTON, D. C. FO COMSUNICATION CENTER USE .

USE WHERE REQUIRED THIS DOCOMENTCONSISTSOF — O PXGES

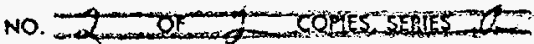

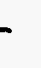

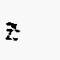
. 


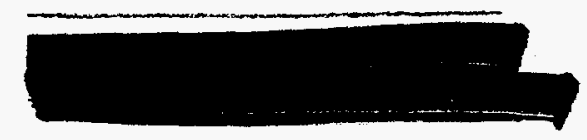

USAEC - ATTN BENGELSDORF

$7-7-71$

$B Y X 71-20$

PAGE TWO

RESPONSIBIUITY OF THIS PROGRAM WOUID BECOME THE MAINTENANCE OF THE STOCKPILE WHICH, AS TIME WENT BY, WOULD CONSIST INCREASINGLY OF OLDER ITEMS AND OLDER DESIGNS. PRESENTIY, PERHAPS 10\% OF THE WEAPONIZATION PROGRAM IS INVOLVED IN STOCKPILE MAINTENATCE WITH THAT FRACTION DOUBLTNG OR TRIPLING WHEN AN EMERGENCY REPLACEMENT IS CALLED FOR. OVER THE YEARS, ONE WOUTD EXPECT THIS FRACTION TO GO UP FROM ITS PRESENT AVERAGE IEVEL, ALTHOUGH BY HOW MUCH IS VERY DIFFICULT TO SAY. MORE INTENSIVE IONG-TERM MATIRIALS AND MATERIAL-AGING STUDIES WOUID IIKELY BE UNDERTAKEN.

IN ADDITION TO THE CHRONOLOGICAL AGING OF THE STOCKPILE, THE WEAPONS DESIGNER WOUTD HAVE TO CONTINUOUSLY REVIEW THE SURVIVABILITY OF THE DETERRENT STOCKPILE AGAINST POSSIBLE

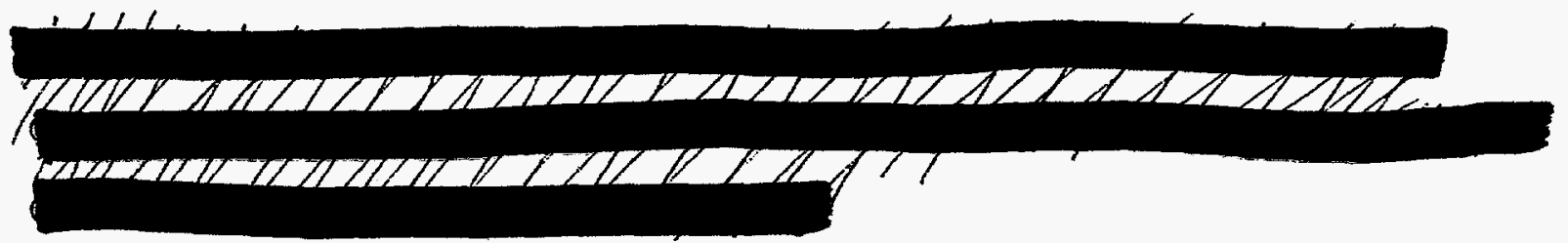

THE JOB OF MODIFYING OR FITTING NEW DESIGNS OF NUCLEAR WARHEADS INTO DIFFERENT DODSYSTEMS WOULD GREATLY DECREASE SINCE CHANGES WHICH COUTD BE MADE IN THE STOCKPITE OF INUCLEAR WARHEADS WOULD BE SHARPLY LIMITED. THE AMOUNT OF WORK WHICE CAN BE DONE UNDER A TEST BAN IN THIS AREA CIEARIY DEPENDS ON WHAT JUDGMENT IS MADE ABOUT HOW CONSERVATIVE CHANGES MUST BE TO BE ACCEPTABLE. IN MY OPINION, NUCLEAR PARTS SHOULD NOT BE CHANGED AT ALI AND THEREYORE THE CHANGES WOUID AMOUNT TO A REPACKAGING, WHERE THE MAIN ROIE PIAYED BY THE LABORATORY WOULD BE TO SEE XX TO IT THAT REPACKAGING DID NOT INTERFERE, TO THE BEST OF OUR CALCULATIONS, WITH NUCLEAR PERFORMANCE.

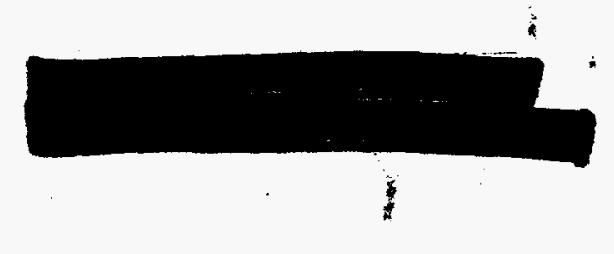




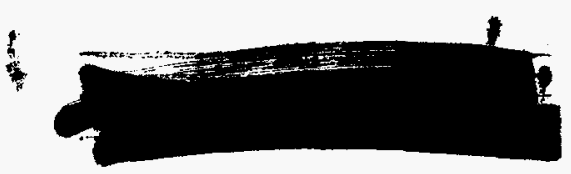

USAEC - ATTN BENGELSDORF $7-7-71$

PARTICIPATION IN PHASE 1 AND 2 DISCUSSION WOULD GO ON AS IT DOES NOW. THE LEVEL OE THIS WORK WOULD DEPEND ON THE DECISIONS OF THE DEPARTMENT OF DEFENSE CONCERNING NUMBERS AND KINDS OF NEW NUCLEAR WEAPONS SYSTEMS THEY WOULD WANT TO PUT INTO OPERATION, USING ESSENTIALLY EXISTING WARHEAD DESIGNS. SINCE NUCLEAR WEAPONS SYSTEMS ARE INITIATED FOR A VARIETY OF REASONS, INCLUDING CHANGES OF MISSIONS, CHANGES OF NONNUCLEAR TECHNOLOGY, AND CHANGES OF TACTICS, IT IS DIFFICULT TO ESTIMATE TO WHAT EXTENT THE DOD WOULD CARRY ON THIS ACTIVITY. OUR PARTICIPATION IN PHASE 1 AND 2 DISCUSS IONS OFTEN INVOIVES OUR CARRYING OUT NUCLEAR EX PERIMENTS TO OBTAIN RELEVANT DATA. THAT PART OF THE EFFORT WOULD OF COURSE TERMINATE.

SUMMARIZING, ONE WOULD EXPECT THAT THE PART OF THE LABORATORY DEVOTED TO WEAPONIZATION WOULD GO DOWN SO FAR AS ENGINEERING AND PHYSICS EFFORT ARE CONCERNED, BUT MIGHT WELL GO UP INSOFAR AS MATERIALS WORK IS CONCERNED. THE NET BALANCE IS SO SENSITIVELY DEPENDENT UPON DOD DECISIONS, THAT I CANNOT HERE ESTIMATE IT.

b. NUCLEAR DESTGN PROGPAV

THE MAIN JOP OF TEE NUCLEAR DES IGN PROGRAM IS TO INVESTIGATE NEW NUCLEAR DESIGNS, BASIC PHYSICS QUESTIONS RELATING TO THEM, AND, TO SOME EXTENT, SOME OF THEIR EFFECTS. CLEARLY, THAT EFFORT WOULD SHARPLY DWINDLE. THERE WOULD BE TWO OR THREE YEARS OF FAIRLY

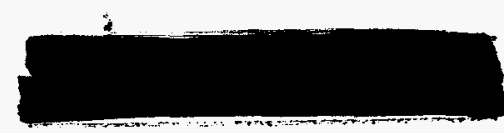


USAEC - ATTN BENGELSDORF $7-7-71$

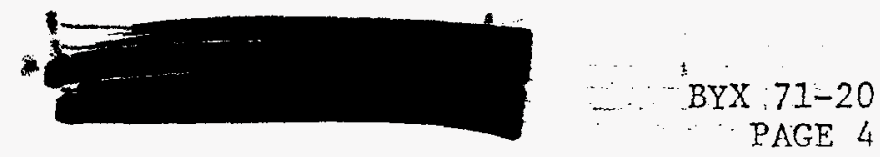

USEFUL WORK TO PUT IN, IN THE REPORT WRITING AND THE CALCULATION INTERPRETATION OF RECENT EXPERIMENTS. IT WOULD BE DIFFICULT TO KEEP FIRST-RATE PEOPLE ON THIS EFFORT, AND THEREFORE, MY GUESS IS THAT IT WOULD EVENTUALLY DIE DOWN SO FAR AS MAKING A SIGNIFICANT CONTRIBUTION TO THE STATE OF THE ART IS CONCERNED.

AN INCREASING FRACTION OF THE PEOPLE INVOLVED IN NUCLEAR DESIGNS COULD QUITE USEFULLY WORK ON ESTIMATING THE NATURE OF NUCLEAR ATTACKS WHICH MIGHT AFFECT THE VULNERABILITY OF PRESENT SYSTEMS IN A NUCLEAR ENVIRONMENT SUCH AS MIGHT BE PRESENT IN A SECOND-STRIKE SITUATION. THE LABORATORY HAS DONE SOME BUT NOT MOST OF THE WORK IN THAT AREA. IT COULD USEFULLY DO A GREAT DEAL MORE. IT COULD AND PROBABLY SHOULD ALSO EXTEND ITS EFFORT INTO DEVISING NUCLEAR SIMULATION TECHNIQUES TO DETERMINE THE VULNERABILITY OF MILITARY COMPONENTS TO NUCLEAR EFFECTS. SUCH AN EFEORT COULD BE QUITE LARGE. IT NOULD INVOLVE SOME NEW SKILLS, A TURNOVER OF PEOPLE, AND AGAIN; ITS EXTENT IS OUITE DIFEICULT TO ESTIMATE. IT COULD BE AS LARGE AS TYE PRESENT NUCYEAR DESIGN EPEORT IF A SERIOUS ATTEMPT WERE MADE TO UTILIZE IABORATORY RESOURCES TO MAINTAIN THE INVULNERABILITY OF DRESENT MITITARY SYSTEMS. CERTAINIY, IN SUCH AREAS AS A PREDICTION Of FALLOUT, PREDICTICN OF EMP, PREDICTION OF GEOMAGNETIC AND OTHER DISTURBANCES FROY VARIOUS KINDS OF BURSTS, THE PREDICTION OF EFEECTS OF DUST ON REENTRY VEYICLE, ETC., THE LABORATORY HAS A HEAD START, AND IN FACT, HAS USUALLY BEEN THE PLACE WHERE NEW CALCULATION EXPERIMENTAI TECHNIQUES WERE INITIATED ALTHOUGH THESE TECHNIQUES WERE USUALLY EXPLOTTED ELSEWHERE. 
USAEC - ATTN BENGELSDORF $7-7-71$

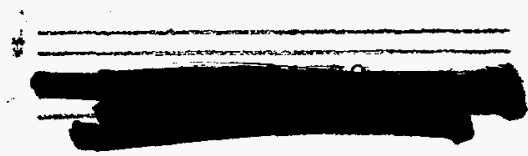

IN ADDITION, THERE ARE AT THE LABORATORY, A NUMBER OF SCIENTISTS WHO HAVE DEVOTED SOME YEARS TO THE STUDY OF THE SEISMIC EFFECTS VERIFICATION

AND OTHER METHODS OF VERIFYING OR EVADING OF NUCLEAR EXPLOSIONS, THOSE PEOPLE WOULD HAVE A CLEARLY EXPANDING ROLE UNDER A NUCLEAR TEST BAN.

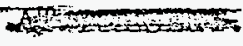

THE NUCLEAR DESIGN PROGRAM AMOUNTS TO ABOUT A THIRD OF THE TOTAL PROGRAM.

\section{c. TEST PROGRAM}

THE TEST PROGRAM WOULD CLEARIY SHARPLY DECREASE IN THE NEEDS PLACED ON IT AND IN ITS MANPOWER. SONE GROUPS WOULD HAVE TO BE RETAINED IF A READINESS POSTURE WERE TO BE MAINTAINED BUT THEY WOULD HAVE TO BE KEPT BUSY ON GENUINELY USEFUL SCIENTIFIC TASKS IF GOOD PEOPLE WERE TO BE KEPT ON BOARD. THE NUMBER OF TASKS WHICH ARE BOTH GENUINELY USEFUL AND CLOSELY RELEVANT TO READINESS-FOR-WEAPONS TESTING IS LIMITED. THEY WOULD INVOLVE IN PART INSTRUMENTATION DEVELOPMENT, IN PART ASTROPHYSICAL OR GEOPHYSICAL MEASUREMENT, AND IN PART (VERY LIKELY) WORK ON THE LASER-INDUCED IMPLOSIONS IF PERMITTED. DEVELOPMENT OF AUTOMATED DIGINAI DATA COLLECTION SYSTEMS, SUCH AS NADS, COULD BE CONTINUED AND APPLIED TO A VARIETY OF $\therefore$ EXPERIMENTAL SYSTEMS. THIS COULD MAINTAIN A GROUP IN DIRECTLY RELATED AND USEFUL WORK. THE TOTAL EFFORT WOULD BE MUCH LESS THAN WHAT IS NOW NEEDED. THE TEST PROGRAM AMOUNTS TO BETWEEN A FIFTH AND A QUARTER OF THE TOTAL PROGRAM. 
USAEC - ATTN BENGELSDORE

\section{d. SUPPORTING RESEARCH}

SOMEWHERE BETWEEN A FIFTH AND A QUARTER OF THE TOTAL WEAPONS

PROGRAM IS DEVOTED TO SUPPORTING RESEARCH IN PHYSICS, COMPUTERS, CHEMISTRY, AND ENGINEERING. UNDER THE ASSUMPTION

THAT THE U.S. WANTS TO MAINTAIN SOME CAPABILITY TO RESUME NUCLEAR WEAPONS DESIGN, MUCH OF THIS COULD AND SHOULD GO ON IN THE EVENT OF A TEST BAN TREATY.

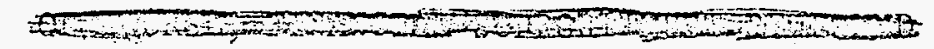

OUR WORK IN NUCLEAR PHYSICS, OUR W'ORK ON HYDRODYNAMICS, ON TRANSFER THEORY, ON MATHEMATICAL METHODS SUCH AS MONTE CARLO METHODS, ALL SERVE A BROADER PURPOSE THAN NUCLEAR WEAPONS DESIGN AND ALSO ARE ESSENTIAL TO MAINTAIN SKILL IN THAT AREA. THESE PROGRAMS ARE LARGELY UNCLASSIFIED AND COULD BE USEFULLY EXPANDED, BUT WOULD, OF COURSE, NOT SUBSTITUTE FOR NUCLEAR DESIGN SO FAR AS ADVANCEMENT OF THE STATE OF THE ART IS CONCERNED. WORK ON MATERIALS AS NOTED ABOVE WOULD HAVE TO EXPAND, IF ONLY IN CONNECTION WITH THE STOCKPILE. FUNDAMENTAL MATERIALS WORK IS GOING ON AT THE LABORATORY, IN BOTH PHYSICS AND CHEMISTRY, AND HAS TO DO WITH BEYAVIOR OF MATERIALS, BOTH UNDER NORMAL CONDITIONS OF STORAGE, AND ALSO UNDER EXPLOSION CONDITIONS. 
THE WORK ON COMPUTERS SYSTEMS SOFTWARE AND COMPUTER CODES WOULD DEPEND SHARPLY ON THE AMOUNT OF WORK WHICH THE PROGRAMMATIC PARTS OF THE EFEORT WOULD CARRY ON. IF THERE IS A GOOD SIZED PROGRAM IN MAINTAINING INVULNERABILITY, COUPLED PERHAPS WITH THE PLOWSHARE PROGRAM, THE LOAD ON COMPUTERS MIGHT REMAIN ABOUT WHERE IT IS NOW, SO FAR AS DEVELOPING NEW CODES AND NEW SOFTWARE IS CONEERNED. IF THERE IS ANY ATTEMPT MADE TO MODIFY NUCLEAR WARHEADS FOR NEW SYSTEMS, THE LOAD ON COMPUTERS COULD GO UP DRASTICALLY, AS PEOPLE ATTEMPTED TO FIND A SUBSTITUTE FOR TESTS. IT IS MY STRONG RECOMENDATION, HOWEVER, THAT WE NOT FOLLOW THIS PATH AND THAT CHANGES IN NUCLEAR COMPONENTS NOT BE MADE. IN SPITE OF THIS RECOMMENDATION, I BELIEVE THAT IN THE COURSE OF TIME, PRESSURE TO MAKE SUCH CHANGES IN ORDER TO IMPROVE OR EVEN MAKE POSSIBLE CERTAIN NEW MILITARY SYSTEMS VAY BE DIFFICULT TO RITHSTAND. IN THAT CASE, THE DEMAND ON COMPUTERS WOULD GREATLY EXCEED WHAT : THE CASE Now.

2. OUTSIDE THE WEAPONS PROGRAY

BECAUSE WITHOUT TESTING THE AMOUNT OF NEW KNOWLEDGE WHICH CAN BE ACCUMULATED IN THE NUCLEAR EXPLOSION AREA IS QUITE LIMITED, AND BECAUSE THE IMPORTANCE OF ACCUNULATING THIS KNOWEDGE WOULD CLEARLY BE DOWNGRADED IN THE MINDS OF PEOPLE INVOLVED, IT WOULD BE QUTTE HARD TO MAINTAIN MORE THAN A SMALL GROUP OF EXFRTS ON TUE RELEVANT FIELDS. THE GOALS OUTLINED IN THE FIRST PART OF THIS ThX WOULD HELP, BUT IN MY OPINION, THEY WOULD NOT BE ENOUGH. SOME NEW MAJOR PROJECT, IN AREAS WHICH MIGHT BE CLOSE 
USAEC - ATTN BENGELSDORF $7-7-71$

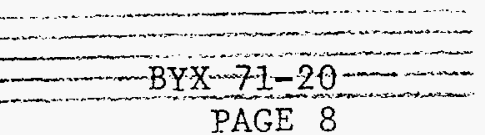

PAGE 8

TECHNICALLY TO THE AREA OF NUCLEAR EXPLOSION, SHOULD BE FOUND. THE LABORATORY'S PRESENT EMBRYONIC EFFORTS IN ATMOSPHERIC POLLUTION AND ATMOSPHERIC MODELING COULD HELP FORM THE SEED OF SUCH A PROJECT, BUT A GREAT DEAL WOULD REMAIN TO BE WORKED OUT, AND IN ANY CASE, THE PROJECT WOULD HAVE TO FULFILL NEEDS CLEARLY RECOGNIZED AND THE LABORATORY WOULD HAVE TO COMPETE IN FULFILLING THESE NEEDS WITH OTHER ORGANIZATIONS. I BELIEVE THAT THESE PROBLEMS COULD BE MET SUCCESSFULLY SO FAR AS EMPLOYMENT OF THE PEOPLE IS CONCERNED. THE NET RESULT SO FAR AS BENEFITS TO : $:$ NUCLER WEAPONS WOULD BE LIMITED TO
CHBORATORY MAINTAINING IN THIS A GROUP OF VERY QUALIFIED PEOPLE WHICH COULD BE CALLED UPON FOR CONSULTANCY, OR IF NEED BE, IN THE CASE OF T T RESUMPTION.

THE NONNUCLEAR WEAPONS PROGRAMS PRESENTLY AT THE LABORATORY WOULD NOT BE STRONGLY AFFECTED BY THE NUCLEAR TEST BAN EXCEPT FOR PLOWSHARE, WHICH I PRESUNE IS BEING DEAIT WITH UNDER A SEPARATE HEADING, THE NONNUCLEAR WEAPONS PROGRAMS AT THE LABORATORY AMOUNT TO APPROYYIMATELY 25\% OF THE TOTAL AT THIS TIME. 